\title{
Konstruksi Keindonesiaan Dalam Film Tjokroaminoto
}

\author{
Ahmad Toni \\ Universitas Budi Luhur, Jakarta \\ ahmad.toni@budiluhur.ac.id
}

\begin{abstract}
This study uses critical discourse analysis method that aims to reveal the meaning of Indonesian keynthones in Tjokroaminoto Guru Bangsa film. The results show that the representation of meaning at Indonesian level at the text level is a representation of the dominance of ethnic or racial tribes of Europe and Arabia and subordinan tribes or races of Javanese, Chinese, Sundanese and do not have citizenship. At the messo level the purpose of the film production system is the goal of Tjokroaminoto's historical reconstruction based on the spirit of Islam as the basis for the struggle. At the macro level shows the construction of national leadership is a rational effort in order to fulfill party politics based on the spirit of keindonesiaan. Keindonesiaan is the essence of the teachings of cultural Islam that upholds human values in order to realize the concept of hijra or civil society in Indonesia.
\end{abstract}

\section{Key Words: Representation of Meaning of Indonesianness, Film of Tjokroaminoto Guru Bangsa}

\begin{abstract}
ABSTRAK
Penelitian ini menggunakan metode analisis wacana kritis yang bertujuan untuk mengungkapkan konstruki makna keindonesiaan di dalam film Tjokroaminoto Guru Bangsa. Hasil penelitian menunjukkan bahwa representasi makna keindonesiaan pada level teks merupakan representasi dominasi suku atau ras Eropa dan Arab dan subordinan suku atau ras Jawa, Tionghoa, Sunda, dan tidak mempunyai kewarganegaraan. Pada level messo tujuan sistem produksi film merupakan tujuan rekonstruksi sejarah Tjokroaminoto yang didasari oleh semangat Islam sebagai dasar perjuangan. Pada level makro menunjukkan konstruksi kepemimpinan nasional merupakan usaha rasional dalam rangka pemenuhan politik kepartaian yang didasari semangat keindonesiaan. Keindonesiaan merupakan hakikat ajaran Islam Kultural yang menjunjung tinggi nilai kemanusiaan guna mewujudkan konsep hijrah atau masyarakat madani di Indonesia.
\end{abstract}

\section{Kata Kunci: Representasi Makna Keindonesiaan, Film Tjokroaminoto Guru Bangsa}




\section{PENDAHULUAN}

Wacana keindonesiaan selalu menjadi persoalan yang dinamis dalam kehidupan berbangsa pasca reformasi 1998 yang membawa sistem demokratisasi dalam berbagai bidang kehidupan. Reformasi dimaknai bagi sebagian warga negara sebagai kebebasan murni tanpa memandang nilai keberagaman sebagai ciri khas bangsa ini. Pluralitas bangsa dimaknai sebagai wahana kepentingan golongan mayoritas dan menyingkirkan ruangruang keterbukaan bagi golongan minoritas, terutama dalam ruang publik dan ruang politik.

Wacana yang dibangun oleh media massa terutama televisi dipenuhi dengan kepentingan kapitalisme yang beriorientasi pada nilai ekonomis dan representasi ideologi golongan tertentu semata. Televisi menjadi alat hegemoni kepentingan dan sumbersumber komoditi bagi pemodal dalam rangka menumbuhkan dan mempengaruhi khalayak untuk menjadi masyarakat konsumtif. Media massa alternatif yang diwujudkan sebagai media identitas bangsa, yakni film. Film sebagai media dan identitas bangsa membawa isu-isu permasalahan sosial dan politik dalam rangka menumbuhkan kesadaran berbudaya melalui hiburan. Film sebagai 'ruang publik politis' dijadikan sebagai alat rekonstruksi pemikiran Tjokroaminoto dalam rangka melawan penjajah, merintis kemerdekaan bangsa yang tujuan utamanya ialah memanusiakan manusia.

\section{KERANGKA PEMIKIRAN}

Teori Wacana

Diskurstheorie atau teori diskursus dalam pandangan Habermas ialah 'Mengarahkan perhatiannya kepada kondisi-kondisi komunikasi yang memungkinkan sebuah praksis pencapaian konsensus dapat dilakukan secara bebas dan fair' (Hardiman, 2016: 24). Pandangan tentang kondisi komunikasi dan pencapaian konsensus didasarkan pada konsepsi tentang masyarakat modern yang terbelanggu dengan aturan-aturan politis. Teori wacana mampu mengarahkan manusia sebagai satu kesatuan secara keseluruhan untuk mencapai tujuan tertentu, dengan menata kembali kehidupan mereka kepada tujuan hidup bersama. Teori wacana bukan menempatkan manusia untuk mencapai tujuan tetapi menempatkan manusia kepada bagaimana manusia melakukan cara-cara atau prosedur-prosedur untuk mencapai tujuan yang diinginkan secara bersama-sama.

Pendapat Hardiman (2009: 2324) tentang teori wacana ialah 'Teori diskursus menawarkan sebuah radikalisasi prosedur komunikasi politis untuk mencapai konsensus dasar atau disebut dengan grundkonsens yang memperkokoh integritas masyarakat dalam suatu negara'. Esensi teori diskursus ialah memberikan sebuah gambaran cara- 
cara radikalisasi komunikasi sebagai prosedur untuk mencapai kesatuan manusia dalam menggapai tujuan, radikalisasi untuk mencapai kesepakatan bersama sebagai kebutuhan konsensus. Epistimologi teori wacana Habermas dinyatakan sebagai: tindakan komunikatif, tindakan komunikatif menjadi dasar seluruh proyek komunikasinya. Usaha menerapkan prinsip-prinsip diskursus pada politik tentang negara hukum demokratis. Diskursus dipahami sebagai prosedur dan bagaimana prosedur ini dapat diterapkan pada proses pencapaian konsensus atas norma-norma yang masih kontroversial.

Konsepsi diskursus dilakukan dengan cara-cara: Rasio Prosedural. Rasio komunikatif sebagai pengganti rasio praktis. Tindakan komunikatif. Lebenswelt, diartikan sebagai duniakehidupan sebagai pelengkap untuk konsep tindakan komunikatif. Diskursus praktis sebagai sebuah proses untuk mencapai konsensus.

Wacana sebagai praksis sosial ditampilkan dalam berbagai bentuk medium komunikasi sebagai alat hegemoni terhadap cara pandang sistem sosial. Wacana sebagaimana dinyatakan oleh Fairclough (Haryatmoko, 2017: 4) 'Wacana adalah praksis sosial dalam bentuk interaksi simbolis yang bisa terungkap dalam pembicaraan, tulisan, kial, gambar, diagram, film atau musik'. Wacana menjadi instrumen yang digunakan untuk tujuan-tujuan sosial, termasuk dalam hal membangun cara pandang sosial atas perubahanperubahan yang terjadi di dalam sistem sosial. Wacana merupakan proses transformasi tanda-tanda yang dilakukan untuk kepentingan hegemoni kekuasaan. Pendapat selanjutnya menurut Haryatmoko (2017: 4) Film sebagai wacana tindakan/act merupakan proses semiotik yang merepresentasikan dunia sosial. Dalam hal ini film karya Garin Nugroho merupakan wacana tindakan yang dikonstruksi oleh Garin Nugroho yang ditujukan kepada khalayak bangsa Indonesia melalui medium film dengan menggambarkan situasi sosial politik yang meletarbelakangi sistem produksinya. Konteks ruang dan waktu dan situasi sosio kultural yang melingkupinya perlu ditelaah lebih mendalam guna mengetahui konstruksi pemikiran dan cara pandang ideologis dari sutradara film. Film karya Garin Nugroho sebagai wacana tindakan dipergunakan untuk memandang situasi dan kondisi sosio kultural bangsa Indonesia. Film yang dimaksudkan ialah film Tjokroaminoto Guru Bangsa yang diproduksi pasca reformasi 1998 dan keterkaitan antara produksi film dengan wacana keindonesiaan yang berkembang pada masa film diproduksi, sehingga tujuan produksi film dengan wacana keindonesiaan dapat ditelaah lebih mendalam.

\section{Wacana dan Keindonesiaan}

Formulasi makna keindonesiaan dalam masyarakat 
Indonesia ditentukan oleh rasa keadilan dan nilai-nilai kemanusiaan yang menjadi dasar bernegara. Keindonesiaan didefinisikan sebagai akumulasi nilai-nilai toleransi dan saling menghargai antar sesama serta menjunjung tinggi kebhinekaan. Kebhinekaan Indonesia sebagai sebuah realitas pluralis memerlukan perubahan paradigma yang mendasar, dari sikap yang mau memonopoli kebenaran kepada sikap yang mau berbagi kebenaran.

'Kebenaran dalam perspektif kemanusiaan yang bulat dan utuh, seluruh suku bangsa dan agama merasa aman dan nyaman hidup di Indonesia. Pilar kemanusiaan hanya bisa tegak dengan kuat, jika prinsip keadilan tidak dipermainkan dengan beraneka alasan' (Wahid, dkk, 2015: 20-21)'. Pemahaman ulang keindonesiaan untuk menyebut kemanusiaan yang utuh dalam berbangsa dan bernegara tidak perlu menerapkan makna dan paham sekterian di dalam kehidupan sosial. Kehadiran paham sekterian dalam berbangsa dan bernegara melahirkan realitas pengkafiran dari satu golongan kepada golongan tertentu, atau antar individu dengan individu tertentu. Realitas pengkafiran didalam kehidupan berbangsa dan bernegara telah memasuki ruang publik media massa, bahkan tanpa diimbangi dengan filter etika dan moralitas. Kondisi moral masyarakat yang saling mengkafirkan antara satu dengan yang lain membahayakan keberlangsungan stabilitas negara maka diperlukan kembali tafsir atas kerangka kebhinekaan dalam kehidupan berbangsa dan bernegara.

$$
\text { Pendapat }
$$

Maarif

'Keindonesiaan dalam arti kebangsaan Indonesia tidak boleh beralih menjadi kebangsaaan yang ekspansif yang tidak lain dari imperialisme modern, baik dalam teori dan praktik nasionalisme terkait dengan mesianisme, ekspansionisme, imperialisme, dan perang" (2015: 30-31). Dasar pendapat Maarif tersebut ialah pernyataan Soekarno tentang nilai kemanusiaan yang dinyatakan pada sila 'Kemanusiaan yang adil dan beradab' dan pendapat Mahatama Gandhi tentang 'my nationalism is humanity". Perspektif kemanusiaan membawa kita kepada pemahaman tentang cara-cara kita berbangsa dan bernegara yang dilandasi oleh asas ketuhanan dan kemanusiaan.

\section{Semiotika Roland Barthes}

Mitologi dapat memiliki suatu fondasi historis, karena mitos merupakan semacam wicara yang dipilih oleh sejarah, mitos tidak mungkin berkembang dari 'hakikat' pelbagai hal" (2007: 296-297). Sementara pengertian mitos menurut Danesi (2010: 57) ialah "kata mitos berasal dari kata Yunani 'mythos' yang artinya 'kata-kata', 'wicara', 'kisah para dewa'. Hal ini bisa didefinisikan sebagai narasi yang di dalamnya karakter-karakter para dewa, makhluk mistis, dengan plot (alur cerita) asalusul segala sesuatu atau tentang 
peristiwa metafisis yang berlangsung di dalam kehidupan manusia, dan setting-nya adalah penggabungan dunia metafisis dengan dunia nyata".

Mitos bagi Barthes ialah tentang tanda adalah peran pembaca (the reader). Baginya, konotasi walaupun merupakan sifat asli tanda, membutuhkan keaktifan pembaca agar dapat berfungsi. Secara panjang lebar, Barthes mengulas apa yang sering disebut sebagai sistem pemaknaan tataran kedua, yang dibangun di atas sistem lain yang telah ada sebelumnya. Sastra misalnya, merupakan contoh paling jelas sistem pemaknaan tataran kedua yang dibangun di atas bahasa sebagai sistem yang pertama. Sistem kedua ini oleh Barthes disebut dengan connotatif, yang di dalam Mythologiesnya secara tegas ia bedakan dari denotatif atau sistem pemaknaan tataran pertama. Melanjutkan studi Hjelmslev, Barthes menciptakan peta tentang bagaimana tanda bekerja Cobley \& Jansz (Sobur, 2003: 69).

\begin{tabular}{|c|c|}
\hline $\begin{array}{c}\text { 1. Signifier } \\
\text { (penanda) }\end{array}$ & $\begin{array}{c}\text { 2. Signified } \\
\text { (petanda) }\end{array}$ \\
\hline \multicolumn{2}{|c|}{$\begin{array}{c}\text { 3.Denotative sign (tanda } \\
\text { denotatif) }\end{array}$} \\
\hline $\begin{array}{c}\text { Connotative } \\
\text { (konotatif) }\end{array}$ & $\begin{array}{c}\text { Connotative signified } \\
\text { (petanda konotatif) }\end{array}$ \\
\hline \multicolumn{2}{|c|}{ Connotative sign (tanda konotatif) } \\
\hline
\end{tabular}

Gambar 1. Sumber, Sobur: 69.

Peta Barthes di atas terlihat menunjukkan bahwa tanda denotatif (3) terdiri atas: penanda (1) dan petanda (2). Akan tetapi, pada saat bersamaan, tanda denotatif adalah juga penanda konotatif (4). Dengan kata lain, hal tersebut merupakan unsur material: hanya jika kita mengenal tanda "singa", barulah konotasi seperti harga diri, kegarangan, dan keberanian menjadi mungkin (Cobley \& Jansz, dalam Sobur 2003: 69). Dalam konsep Barthes, tanda konotatif tidak sekedar memiliki makna tambahan namun juga mengandung kedua bagian tanda denotatif yang melandasi keberadaannya. Sesungguhnya, inilah sumbangan Barthes yang sangat berarti bagi penyempurnaan semiologi Saussure, yang berhenti pada penandaan dalam tataran denotatif.

\section{Film}

Film yang dimaksudkan ialah film fiksi, film fiksi ialah film yang diproduksi berdasarkan atas ide dan gagasan seorang penulis naskah, bentuknya ialah imajinasi murni, hasil 
rekaan ide, dan tidak berdasarkan atas kronologis realitas murni, namun dalam beberapa film justeru lahir atas dokumentasi pengungkapan realitas kehidupan yang kemudian dilakukan sistem narasi dramatisir untuk membangun emosi dalam proses penceritaan di dalam film. Sebagaimana dinyatakan oleh Pratista (2008: 6-7) "Film fiksi terikat oleh plot. Dari sisi cerita, film fiksi menggunakan cerita rekaan di luar kejadian nyata serta memiliki konsep pengadegan (fragmen) yang telah dirancang sejak awal. Film fiksi antara nyata dan abstrak, baik secara naratif maupun secara sinematik sering menggunakan pendekatan dokumenter". Selanjutnya Pratista (2008: 9-10) "Adapun metode yang paling mudah kita gunakan untuk mengklasifikasi film adalah berdasarkan genre (jenis), seperti aksi, drama, horor, musikal, western dan sebagainya". Film pada dasarnya dilihat dari isi cerita dalam membagi jenis dan klasifikasinya dalam perkembangannya yang mulai banyak diproduksi. Dari masa ke masa film semakin berkembang demikian pula genrenya. Genre lahir dari tren dan dihasilkan pada selera masyarakat yang mewakilinya.

\section{METODE PENELITIAN}

Analisis wacana kritis (CDA) memiliki dua model, yaitu CDA model Norman Fairclough yang melihat teks (naskah) memiliki konteks dan CDA dari Ruth Wodak yang menilai teks (naskah) mempunyai sejarah' (Hamad, 2008:17-20).

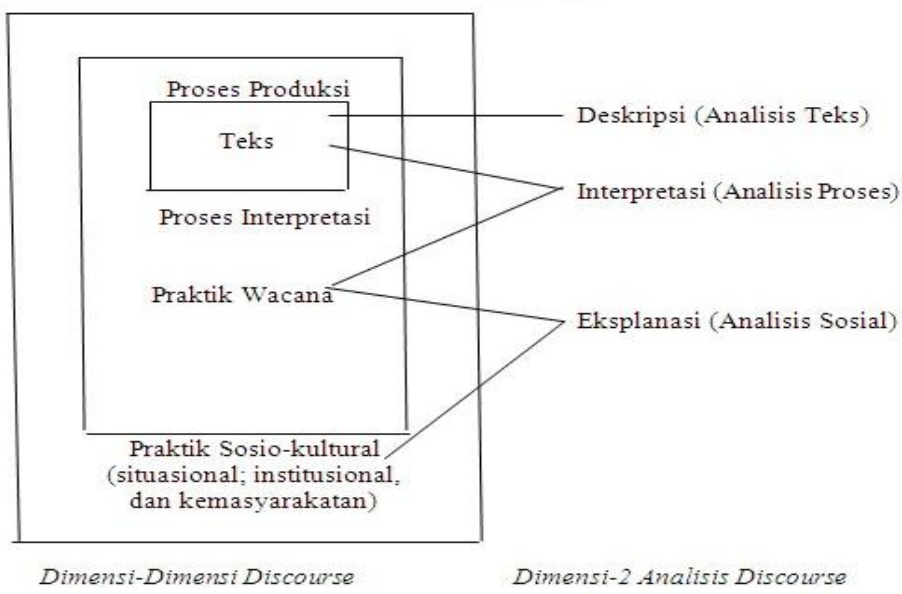

Gambar 3. CDA Norman Fairclough (Hamad, 2005: 228)

Analisis wacana menurut Fairclough (2010: 74-75) meliputi:
1. Struktur sosial yang didasarkan pada sistem semiotik (languages) 
2. Praktik sosial, wacana lain dari wacana dirinya, yaitu sistem produksi wacana dan tujuan dari produksi wacana.

3. Acara khusus (special event), tipe wicara atau pembicaraan yang terjadi dalam suatu sistem sosial yang dilaksanakan untuk tujuan atau agenda khusus.

Analisis wacana kritis Menurut Fairclough menempatkan level teks dapat dilakukan dengan pendekatan analisis semiotik dengan berbagai varian analisisnya sesuai dengan dimensi persoalan yang berhubungan dengan konteks dan praktik-praktik wacana yang melingkupinya. Penelitian ini menggunakan analisis wacana dan guna menganalisis teks menggunakan analisis semiotik untuk menelaah tentang jenis wacana-wacana yang berorientasi pada hubungan wacana antar teks, aksi pragmatik, representasional, identifikasi makna yang terdapat pada bentuk-bentuk teks karya film Garin Nugroho, serta hubungan teks dengan konteks sosial.

\section{HASIL DAN PEMBAHASAN}

\section{Teks Film}

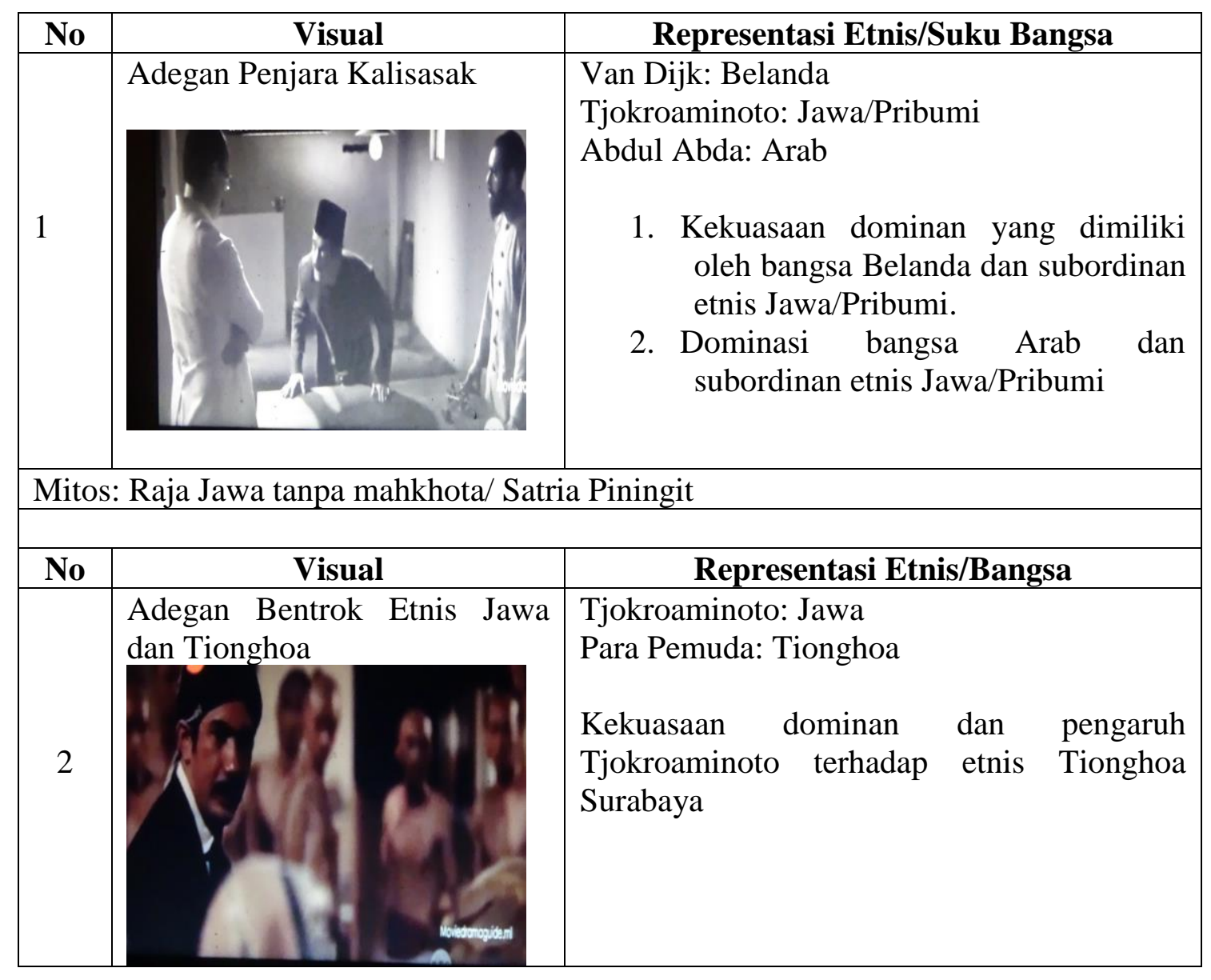


Mitos: Satria Piningit

\begin{tabular}{|c|l|l|}
\hline No & \multicolumn{1}{|c|}{ Visual } & \multicolumn{1}{c|}{ Representasi Etnis/Bangsa } \\
\hline $\begin{array}{l}\text { Adegan Stella menanyakan } \\
\text { nama bangsa yang } \\
\text { diperjuangkan Tjokroaminoto }\end{array}$ & $\begin{array}{l}\text { Tjokroaminoto: Jawa } \\
\text { Stella: Campuran, Bali dan Belanda }\end{array}$ \\
& $\begin{array}{l}\text { Jawa sebagai etnis dominan dan identitas } \\
\text { anak yang tidak memiliki kewarganegaraan }\end{array}$ \\
\hline Mitos: Satria Piningit
\end{tabular}

\begin{tabular}{|c|l|l|}
\hline No & \multicolumn{1}{|c|}{ Visual } & \multicolumn{1}{c|}{ Representasi Etnis/Bangsa } \\
\hline 4 & $\begin{array}{l}\text { Adegan Pertemuan Agus Salim } \\
\text { dan Tjokroamnoto }\end{array}$ & $\begin{array}{l}\text { Agus Salim: Melayu } \\
\text { Tjokroaminoto: Jawa } \\
\text { Dominasi pengaruh etnis Jawa terhadap etnis } \\
\text { Melayu }\end{array}$ \\
\hline \multicolumn{2}{|l|}{ Mitos: Satria Piningit }
\end{tabular}

\begin{tabular}{|c|l|l|}
\hline No & \multicolumn{1}{|c|}{ Visual } & \multicolumn{1}{c|}{ Representasi Etnis/Bangsa } \\
\hline 5 & $\begin{array}{l}\text { Adengan Pemecatan Buruh } \\
\text { Kebun di Garut }\end{array}$ & $\begin{array}{l}\text { Mandor Kebun: Sunda } \\
\text { Dominasi pengaruh etnis Jawa terhadap } \\
\text { etnis Sunda }\end{array}$ \\
\hline Mitos: Satria Piningit & \\
\hline
\end{tabular}

Signifikansi Pertandaan Tjokroaminoto dan Mitos Satria Piningit 
Tokoh Tjokroaminoto direpresentasikan sebagai 'Satria Pinggit" sebuah tokoh mitos yang mampu membawa rakyat Jawa kepada zaman bebas dari penderitaan, yang mampu mensejajarkan dan menghapus kelas sosial, memerdekaan rakyat dari penderitaan dan kesengsaraan. Hal ini ditandainya dengan semangat Tjokroaminoto yang tidak memperbolehkan setiap manusia yang menyembah manusia. Sebagai orang yang membawa semangat kemerdekaan atas bangsa penjajah, Tjokroaminoto ditempatkan sebagai Raja Jawa yang tidak bermahkhota.

\begin{tabular}{|l|l|}
\hline Signifier & $\begin{array}{l}\text { Signified } \\
\text { Anak dari Kiyai Bagoes } \\
\text { Kesan Basri }\end{array}$ \\
\hline Seorang Laki-laki & $\begin{array}{l}\text { Signified (2) } \\
\text { Melawan penjajah untuk } \\
\text { memerdekakan bangsaanya }\end{array}$ \\
Oemar Said Tjokroaminoto & \\
\hline $\begin{array}{l}\text { Sign (2) } \\
\text { Satria Pinggit }\end{array}$ \\
\hline
\end{tabular}

Pertandaan dalam makna denotatif Seorang Laki-laki (Singifier) putera dari Kiyai Bagoes Kesan Basri (Signified) ialah 'Tjokroaminoto' (Sign). Dalam makna tataran konotatif 'Tjokroaminoto' (Sign) yang melakukan perlawanan kepada penjajah (Belanda) merupakan representasi dari 'Satria Pinggit'. Sebagai sebuah tanda perlawanan kepada bangsa penjajah, 'Tjokroaminoto' juga merepresentasikan kepemimpinan Islam yang membumi, ia meletakan dasar-dasar paham memanusiakan manusia seutuhnya. Pada sisi lain tanda 'Tjokroaminoto' merupakan representasi kekuatan Jawa untuk melakukan perlawanan kepada bangsa penjajah. Selanjutnya, 'Tjokroaminoto' direpresentasikan sebagai bapak bangsa, yang meletakan dasar-dasar sistem politik, perserikatan, koperasi dan pencetak generasi muda bangsa yang brilian, dengan latar belakang ideologi dan paham yang dianutnya.

Ia sebagai tanda dari 'Satria Pinggit' yang mampu memenuhi keinginan dan harapan rakyat Jawa akan datangnya sosok penyelamat yang diyakini muncul dari kalangan Rakyat Jawa itu sendiri. Hal ini menjadi proses pertandaan yang rumit dan menyeluruh (holistic) yang menempatkannya berada pada wilayah rasionalitas dan wilayah mistis. Hubungan yang menempatkan dirinya sebagai tanda seorang Jawa yang mampu melawan penjajah, mensejajarkan derajat manusia, dan memerdekakan hak-hak bangsa, mewujudkan impian dan cita-cita setiap warga negara untuk bebas dan merdeka dari penjajahan. Satria 
panggit sebagai sebuah metafora dalam penandaan 'Tjokroaminoto' kesepadanan pertandaan yang bersifat spiritual, di mana beliau dicitrakan sebagai entitas yang konkret, yang termanifestasikan dari perilaku dan tindakan yang dilakukan untuk bangsanya. Beliau merupakan kecakapan wicara dalam perilaku (parapraxis, neurosis), ia dan segala perilakukanya didefiniskan sebagai second order system dari tanda asisoatif antara konsep raja Jawa dan citra yang memerdekan bangsanya sendiri dari hegemoni kekuasaan penjajah.

'Satria Pinggit' sebagai bahasa kedua, atau metabahasa (penghalusan) untuk menunjuk tanda 'Tjokroaminoto' (bentuk) sebagai tanda global dan universal, terma ini meminjamkan dirinya kepada mitos Raja Jawa. Fungsinya adalah untuk penandaan (Signifying) yang mengacu kepada harapan semua orang. Namun sebagaai sebuah mitos yang ditampilkan untuk sebuah harapan, 'Tjokroaminoto' berada pada sebuah keambiguan makna. Pada satu sisi ia tampil sebagai makna Raja yang dalam paham rakyat Jawa wajib disembah sebagai penghormatan kepada titisan Tuhan, paham yang selama ini mereka yakini sebagai sebuah doktrin sosial. Namun disisi lain 'Tjokroaminoto' ditampilkan kosong dari makna tersebut. 'Tjokroaminoto' justeru membangun makna sebagai pemimpin modern yang rasional dan meninggalkan semua bentuk-bentuk penghormatan ala raja terdahulu, ia meletakan dasar berdiri sama tinggi, namun yang perlu ditekankan dalam sistem sosial pada zaman itu ialah pemikiran yang rasionalitas untuk mengusir penjajah dari Indonesia. Justeru 'Tjokroaminoto' pada sisi ini menjadi makna kepemimpinan modern sebagai upaya mempostulasikan diri kepada upaya pembacaaan dan atau pemahaman (reading) sebagai sebuah realitas Indonesia, realitas kepemimpinan yang bersifat empiris dan rasionalis.

Sebagai sebuah tanda untuk representasi Raja Jawa, sosok 'Tjokroaminoto' meninggalkan kemungkinan-kemungkinan rasionalis, untuk mengkosongkan makna 'Raja Jawa' yang sudah bersifat laten dalam sistem sosial masyarakat Jawa dan Indonesia. Ia dengan pemikirannya, perilakunya, sikap kepemimpinannya mulai berupaya mengkikis semua keyakinan tersebut dengan melakukan tindakan yang abnormal pada jamannya. Tentunya hal ini mendapat penolakan dari keluarga, lingkungan dan orang-orang yang secara sosial mempunyai kedudukan dan kekuasaan, termasuk juga Belanda dan Jepang yang berkuasa pada saat itu. Karena tindakan 'Tjokroaminoto' yang abnormal pada masanya tersebut akan menjadi ancaman bagi kelanggengan kekuasaan yang mereka miliki.

Akan tetapi prinsip dasar memanusiakan manusia Indonesia sebagai prinsip hakiki yang dinyatakan 'Tjokroaminoto' dan upaya-upaya 
tindakan dan perilakunya sebagai pemiskinan makna Raja Jawa, makna raja yang mulai kehilangan nilainya, untuk menjinakkan realitas dengan sistem kelas sosial, dan mendefiniskan dirinya sebagai pemimpin baru yang modern.

Citra 'Tjokroaminoto' sebagai 'Satria Pinggit' menjadi pudar untuk mengisi makna kepemimpinan bagi bangsa Indonesia modern dan rasional, tentunya hal ini disertai dengan segala bentuk kegiatan yang dilakukannya untuk membuktikan bahwa kepemimpinan modern Bangsa Indonesia ini dibangun berdasarkan pada rasionalitas dalam hal berpolitik, berdikari dalam bidang ekonomi dengan menggalakan perserikatan, Serikat Dangang Islam (SDI) menjadi Serikat Indonesia (SI), membangun koperasi, dan melakukan perlawanan kepada bangsa penjajah bukan dengan kekerasan tetapi dengan cara-cara diplomasi dan berpolitik. Bahkan ia selalu menegaskan bahwa politik itu jangan pernah dilumuri dengan darah.

Hubungan yang menyatu antara kepemimpinan baru 'Tjokroaminoto' dengan kosep mitos 'Satria Pinggit' atau Raja Jawa secara hakiki merupakan hubungan deformasi. Bahwa telah terjadi kegagalan citra 'Satria Pinggit' atau Raja Jawa pada keyakinan masyarakat Jawa dan Indonesia. Kemudian makna tersebut akan menjadi kabur atau semu, disusul dengan makna lain tentang kepemimpinan bagi bangsa Jawa dan bangsa Indonesia itu adalah pemimpin, yang mampu memimpin rakyat untuk bersatu, berserikat, berdikari dalam bidang ekonomi dan menjadi konstituen partai politik yang kritis terhadap persoalan-persoalan bangsa. Pemikirannya tentang partai politik yang tidak mampu menuntaskan persoalan ekonomi konstituennya adalah bentuk pembodohan yang nyata. Artinya kepemimpinan merupakan bentuk penghalusan makna dan tanda untuk 'Satria Pinggit' atau Raja Jawa, konsep kepemimpinan ini muncul sebagai sebuah kesadaran rasional yang benar-benar menandakan (Signifying) bagi setiap warga negara Indonesia bisa menjadi pemimpin dengan syarat-syarat kepemimpinan yang digagasanya.

Implikasi moral dan spiritual dari mekanisme yang telah digagas oleh 'Tjokroaminoto' melampaui batas-batas rasionalitas bangsa Indonesia. Ia menunjukan keberadaan sikap kemajemukan dan keragaman bangsa ini untuk dihubungkan dengan konsep identitas bangsa yang plural. Penjelasan tersebut berdasarkan pada wacana kepemimpinan Indonesia modern meminta keterangan (interpellant) bagi semua warga negara sebagai penanda dan sekaligus tanda kepemimpinan Indonesia. Sementara realitas wacana "Satria Pinggit" atau Raja Jawa dibekukan dengan sejumlah alasan yang digagas oleh 'Tjokroaminoto' untuk menjadi wacana yang netral bahkan tidak bernilai karena sistem sosial politik 
yang sudah tidak kontekstual dengan keadaan.

Gagasan dalam membangun wacana kepemimpinan Indonesia modern dalam film ini sangat cerdas. Hal ini dibuktikan dengan realitas yang dipolitisasi sebagai sebuah narasi cerita. Bahwa realitas 'Satria Pinggit' atau Raja Jawa sebagai wacana terbesar sepanjang masa sejarah tanah Jawa dimunculkan sebagai sebuah persoalan ideologi Jawa yang menjunjung tinggi nilai-nilai kelas sosial. Namun untuk mengkikis makna itu, sutradara mengajukan argumentasi-argumentasi rasional yang digagas oleh 'Tjokroaminoto' dengan gagasan besar tentang berdirinya bangsa Indonesia. Tentunya gagasan-gagasan 'Tjokroaminoto' yang ditampilkan menjadi alat untuk membekukan makna mitos tentang kepemimpinan Indonesia prakemerdekaan menuju bangsa Indonesia yang merdeka. Karena mitos adalah realitas dan wacana yang berkembang dalam sebuah realitas dan didepolitisasi oleh kepentingan ideologi yang berkuasa pada zamannya. Gagasan-gagasan 'Tjokroaminoto' yang dikemukakan dalam film sebagai justifikasi alami dan abadi, merupakan pernyataan fakta sejarah (statement of fact) tentang berbagai kolonialisme.

Ideologi yang diusung oleh tokoh 'Tjokroaminoto' ialah ideologi bagaimana manusia Indonesia dipandang sebagai manusia yang utuh, bukan dipandang sebagai seperempat manusia, paham tentang kemanusiaan ini tercermin dalam film dan disebut empat (kali) oleh 'Tjokroaminoto'. Nilai-nilai kemanusiaan dan makna kemanusiaan menjadi perhatian utama dalam narasi film. Sementara paham Islam yang direpresentasikan oleh dialog 'hijrah' 'Tjokroaminoto' disebut dalam film sebanyak dua puluh lima kali sepanjang narasi film, sementara kata 'Iqra' disebut sebanyak empat (4) kali sepanjang film. Sementara 'Tjokroaminoto' dipandang sebagai perwujudan 'Satria Pinggit" Raja Jawa tanpa mahkota yang mampu membawa nilai-nilai keadilan "ratu adil' menjadi paham yang tertanam dalam semua benak rakyat. Dalam konteks Islam sebagai agama dan Nabi Muhammad diutus untuk memuliakan akhlak manusia, memanusiakan manusia. Konsep pemuliaan manusia ini yang berasal dari gagasan dan pembacaan Tjokroaminoto atas realitas (iqra) menjadi dasar bagi perjuangannya tentunya menjadi sejalan dan menjadi pengtahuan yang padu dengan konteks sosial Indonesia yang pluralis.

Dalam tafsir multikultural 'Tjokroaminoto' meletakan persamaan hak dan kewajiban kepada semua orang, dengan latar belakang etnis yang beragam, suku, ras dan bangsa termasuk memanggap kaum penejajah sebagai manusia seutuhnya. Sebagaimana persoalan etnis yang terjadi dalam konteks bangsa ini berdiri, mereka sebagai etnis minoritas selalu disudutkan. Kesadaran nilai 'Tjokroaminoto' yang memuliakan 
etnis China, anak-anak yang lahir dari bangsa Eropa menjadi keberagaman gagasan besarnya". Sementara nilainilai nasionalisme yang diusung dalam film ini ialah bagaimana gagasan besar negara ini berdiri serta peletakan dasardasar berkumpul dan berorganisasi, mendirikan basis ekonomi melalui sistem koperasi bagi para petani, pedagang dan lain-lain menjadi rujukan bagaimana kecintaan tokoh ini menjadi dasar peletakan bangsa Indonesia untuk merdeka dari kaum penjajah.

\section{Sistem Produksi}

Tujuan produksi film layar lebar/bioskop bukan untuk mencari keuntungan tetapi lebih kepada misi keluarga besar HOS Tjokroaminoto dan Yayasan Keluarga Besar Tjokroaminoto untuk memberikan informasi tentang gagasan-gagasan Tjokroaminoto kepada generasi muda Indonesia. Keputusan untuk menggunakan media film layar lebar/bioskop terjadi setelah beberapa kali mengadakan rapat pertemuan untuk membahas media yang tepat untuk melakukan transformasi gagasan-gagasan Tjokroaminoto mengenai kepemimpinan, maka terjadi kesepakatan diantara keduanya, kesepakatan media film layar lebar sebagai media yang tepat untuk melakukan transformasi gagasangagasan Tjokroaminoto kepada generasi muda bangsa.

Tujuan produksi film Tjokroaminoto Guru Bangsa meliputi: Pertama, kesadaran masyarakat terhadap ide/gagasan Tjokroaminoto. Kedua, pesan dalam film dapat membangkitkan kembali pemikiran Tjokroaminoto tentang kebangsaan. Ketiga, tafsir lain atas pemikiran Tjokroaminoto dapat berkembang menjadi sumber pengetahuan bagi masyarakat Indonesia. Selain tujuan keluarga besar Tjokroaminoto, film ini pula memberikan ruang alternatif pemikiran tentang nilai sejarah bangsa Indonesia yang digagas berdasarkan cara pandang dan kepentingan multikultural. Landasan semangat kebangsaan ini menjadi pemikiran bersama generasi muda Indonesia dalam mewujudkan keadilan sosial. Sehingga proses membangun bangsa Indonesia ke depan menjadi bangsa yang menjunjung tinggi semangat dan nilai-nilai plural.

\section{Konteks Sosio Kultural}

Konteks sosiokultural bangsa Indonesia dalam hal kepemimpinan selalu menjadi wacana berbagai kalangan untuk menemukan format pemimpin Indonesia masa depan. Hal ini ditandai di setiap menjelang pemilihan Predisen dan Wakil Presiden sebagai representasi atas kepemimpinan bangsa Indonesia. Esensi kepemimpinan nasional selalu merujuk kepada etnis mayoritas Jawa yang hampir menguasai seluruh lini kehidupan berbangsa dan bernegara, sedangkan bangsa ini mempunyai ratusan etnis lain yang dalam konteks berdemokrasi, etnis minoritas yang 
jumlahnya ratusan ini pun mempunyai hak yang sama untuk menjadi pemimpin Indonesia. Kehadiran Jawa dalam wacana pemimpin nasional menjadi magnet bagi segenap pembicaraan lima tahunan menjelang pilpres, sebagai bukti kapabilitas seorang pemimpin yang mampu membawa perubahan bangi bangsa Indonesia. Berikut data presiden berdasarkan kepada etnis dan agama yang melatarbelakanginya:

\begin{tabular}{|l|l|l|}
\hline \multicolumn{1}{|c|}{ Nama } & \multicolumn{1}{|c|}{ Etnis } & $\begin{array}{l}\text { Keyakinan } \\
\text { /Agama }\end{array}$ \\
\hline Ir. Soekarno & $\begin{array}{l}\text { Jawa } \\
\text { Jawa Timur }\end{array}$ & Islam \\
\hline Soeharto & $\begin{array}{l}\text { Jawa } \\
\text { Yogykarta }\end{array}$ & Islam \\
\hline Bachruddin Jusuf Habibie & $\begin{array}{l}\text { Sulawesi } \\
\text { Selatan }\end{array}$ & Islam \\
\hline Abdurahman Wahid & $\begin{array}{l}\text { Jawa } \\
\text { Jawa Timur }\end{array}$ & Islam \\
\hline Megawati Soekarnoputri & Jawa & Islam \\
\hline Susilo Bambang Yudhoyono & $\begin{array}{l}\text { Jawa } \\
\text { Jawa Timur }\end{array}$ & Islam \\
\hline Joko Widodo & $\begin{array}{l}\text { Jawa } \\
\text { Jawa Tengah }\end{array}$ & Islam \\
\hline
\end{tabular}

Data diolah: www.profil.merdeka.com dan www.bio.or.id

Kepemimpinan Indonesia didominasi oleh etnis Jawa, mereka yang berasal dari Jawa ialah Ir. Soekarno, Soeharto, Megawati Soekarnoputri, Susilo Bambang Yudhoyono dan Joko Widodo. Dua nama terakhir dilahirkan dari sistem pemilihan secara langsung oleh Rakyat Indonesia melalui Pemilihan Presiden tahun 2004 dan Pemilihan Presiden kedua pada tahun 2009 yang mengantarkan Susilo Bambang Yudhoyono sebagai presiden dua periode, sedangkan Pemilihan Presiden pada tahun 2014 yang mengantarkan Joko Widodo sebagai presiden pilihan rakyat secara langsung. Sementara BJ Habibie yang menggantikan Soeharto dan membawa reformasi di segala aspek kehidupan bangsa ini sifatnya ialah menggantikan Soeharto yang digoyang dan dituntut mundur oleh berbagai kalangan. Secara esensi dominasi Jawa dalam kepemimpinan nasional bangsa ini dibuktikan oleh pengangkatan dan pemilihan orang Jawa sebagai pemimpin bangsa Indoensia.

Dominasi kepemimpinan secara keyakinan agama Islam sebagai pembuktian atas mayoritas agama yang dianut oleh penduduk Indonesia menempatkan agama Islam sebagai agama dominan dalam kepemimpinan nasional. Agama menjadi magnet tersendiri bagi berbagai kalangan untuk menentukan pemimpin bangsa ini, terlebih lagi pascareformasi 1998 
isu agama menjadi isu sensitif dan terpenting untuk melahirkan pemimpin nasional. Agama dijadikan sebagai alat perjuangan untuk melahirkan pemimpin bagi bangsa ini, dalam berbagai kampanye dan pendekatan kekuasaan bagi terbentuknya sikap pemimpin bangsa yang multikultural ini.

\section{Kepemimpinan Islam Dan Etnis Mayoritas}

Perolehan suara partai Islam membawa implikasi dalam berbagai kehidupan berbangsa dan bernegara. Persoalan kepemimpinan mayoritas dalam berbangsa sebenarnya memberikan potensi umat Islam yang menjadi dominasi elemen masyarakat Indonesia, potensi untuk mewujudkan kepemimpinan Islam sampai saat ini, pascareformasi belum terwujud dengan baik. Dimana sistem liberal perpolitikan di Indonesia tidak melahirkan kepemimpinan mayoritas berdasarkan pada faktor agama, secara suku, Jawa menjadi dominasi kepemimpinan nasional. Artinya kuantitas penduduk muslim di Indonesia belum mampu melahirkan kepemimpinan nasional yang mampu membawa bangsa ini kepada civiel society (masyarakat madani).

Disamping itu umat Islam harus memperkuat peran politik dalam liberalisasi demokrasi untuk melahirkan kepemimpinan nasional yang dilahirkan dari umat Islam. Di mana partai politik Islam menjadi pilar utama dalam membentuk kepribadian kepemimpinan nasional yang mempunyai integritas baik dalam berbangsa dan bernegara, isu formalitas Islam menjelang pemilu presiden bukan isu utama untuk melahirkan kepemimpinan nasional dari umat Islam, melainkan bagimana isu-isu berbangsa dan bernegara dalam perspektif keindonesiaan mampu sejalan dengan konsepsi kepemimpinan Islam sebagai mayoritas penduduk bangsa ini. Isu berbangsa merupakan sikap atas pemenuhan aspirasi konstituen umat Islam dan regulasi politik Indonesia dan kebijakan penyelenggaraan negara dalam sistem demokrasi terbuka pascareformasi.

Kepemimpinan dalam perspektif Islam meliputi:

a. Sikap terhadap golongan Islam, yang mampu mengakomodir kepentingan dari berbagai golongan Islam di Indonesia, seperi: Muhammadiyah, Nahdlautul Ulama sebagai organisasi masyarakat terbesar di negara ini, tentunya dapat merangkul golongan-golongan lain.

b. Sikap sesama umat Islam yang mempunyai keadilan dan kejujuran sejalan dengan nilai agama untuk kepentingan bersama yang berkeadilan.

c. Sikap sebagai pemimpin bangsa yang diimplementasikan dalam wujud amanah bagi semua golongan, suku, ras, agama dan 
lain-lain untuk melahirkan masyarakat madani.

Civiel society dalam diskursus Islam dalam politik nasional merupakan perubahan sosial politik yang ditandai dengan pertumbuhan ekonomi dan pembangunan, kemunculan kelas menengah yang signifikan sebagai indikator pengentasan kemiskinan, kebangkitan Islam melahirkan pimpinan yang mampu mengayomi semua kelompok minoritas, sistem demokratisasi yang melahirkan keinginan publik terpenuhi dalam berbagai bidang kehidupan, dimana nilai-nilai kewargaan dan kehidupan menjadi orientasi utamanya. Seiring dengan dilahirkannya sistem keterbukaan politik, keterbukaan informasi, munculnya partai politik berasaskan Islam, peran organisasi masyarakat Islam yang besar dalam kebijakan negara, harus disertai dengan ekspresi politik Islam yang dapat menunjukkan penerimaan semua lapisan masyarakat dengan agenda visi dan misinya yang mampu diterima oleh semua kalangan.

Pada esensinya partai-partai politik Islam berpartisipasi dalam pesta demokrasi secara prosedural yang memunculkan kepemimpinan Islam dengan mengembangkan dan mengimplementasikan nilai-nilai demokrasi. Manurut Hikam (1996: 230) "perwujudan nilai-nilai Islam yang berhubungan dengan sikap toleransi, perlindungan hak dasar yang berkeadilan, tradisi komunitas Islam dan kemandirian penguasa, pemihakan
Islam kepada minoritas akan melahirkan Civiel Society". Dalam konteks keindonesiaan potensi nilainilai kultural bangsa ini mampu berkontribusi dalam proses konsolidasi demokratis. Persingungan utama Islam dan demokrasi ialah pemahaman ajaran-ajaran keagamaan yang dapat diwujudkan dalam sistem demokrasi dalam berbagai aspek kehidupan dan teraplikasikan dalam tataran normatif berbangsa. Keragaman organisasi Islam di Indonesia sebagai modal sosial yang mampu melahirkan kepemimpinan mayoritas Islam dalam pentas politik nasional.

Gagasan utama civiel society adalah nilai pluralisme, demokrasi, hak asasi manusia untuk memperjuangkan nilai-nilai kemanusiaan. Hal ini sejalan dengan konsep civiel society dalam perspektif Islam, di mana dasar kemanusiaan dan penghargaan terhadap diferensiasi, suku, ras yang beragam untuk saling memahami dan mengasihi. Gagasan ini diaplikasikan oleh organisasi masyarakat yang berlandaskan Islam, NU dan Muhammadiyah yang banyak pada pemberdayaan masyarakat yang dilakukan melalui pelayanan kesehatan, pendidikan, organisasi pengkaderan dan kepemudaan untuk menunju kesadaran masyarakat yang memiliki peran penting bagi terselenggaranya sistem sosial yang lebih baik. Sebagai sebuah gerakan kultural, pemberdayaan ini mestinya mampu membangun wacana sosial budaya yang secara substansi sebagai gerakan 
perlawanan terhadap kultur yang menghegemoni dominasi pahampaham yang melawan negara dalam berkehidupan bangsa. Pembumian gagasan ini sebagai resistensi pertentangan kultural antara pahampaham kontra negara yang banyak terjadi dalam pemikiran umat Islam di kalangan bawah dan kurang terdidik. Sementara Muhammadiyah dalam posisi organisasi keagamaan yang memfokuskan pada pendidikan dan kesehatan serta pemberdayaan lainnya baik kepemudaan dan pengkaderan harus juga mampu menanamkan nilai demokrasi, toleransi, perlindungan kaum minoritas dan nilai-nilai pluralisitas lain.

Dengan demikian secara sistematis, organisasi kemasyarakatan seperti NU dan Muhammadiyah mampu memberikan kontribusi besar bagi bangsa ini untuk memandang demokratisasi dan regulasinya baik dalam pemilu maupun pilpres mampu melahirkan pemimpin nasional yang terstruktur, bukan berdasarkan pada moment politik pesta demokrasi yang dilakukan berdasarkan koalisi partai politik Islam. Hal ini menandai bagaimana cara kerja NU dan Muhammadiyah menunjukkan sikap dan posisinya sebagai organisasi masyarakat Islam secara modern menunjung tinggi nilai-nilai kebangsaan yang tercerminkan melalui kader yang dipersiapkan untuk menjadi pemimpin nasional, baik dalam keterwakilan di legislatif maupun di eksekutif, terutama pada pemilihan presiden secara terbuka.

\section{KESIMPULAN}

Peran civiel society dalam perspektif Islam untuk memunculkan kepemimpinan Islam sebagai mayoritas perlu diintegrasikan kembali dalam konsolidasi demokrasi di Idonesia. Dalam konteks politik Indonesia persoalan struktural pada proses penyelenggraaan negara, pada sistem masyarakat, di mana kekuatan kultural berjalan searah dengan sistem demokrasi yang menyuburkan praktekptaktek korupsi yang melibatkan tokoh dan figur yang dilahirkan dari partai Islam. Sejalan dengan hal itu, memunculkan sikap apatisme dari berbagai kalangan Islam lainnya yang memupuk fenomena radikalisme Islam sebagai sebuah gerakan untuk mewujudkan kepemimpinan dan negara Islam sebagai wujud ketidakpuasan atas kepemimpinan dan demokrasi bernegara. Peran dan kontribusi umat Islam yang mempunyai kapasitas dan kemampuan untuk dapat mempengaruhi iklim politik nasional dan pengambilan kebijakan, sebagai bentuk penentu roda kepemimpinan nasional melalui partai politik Islam. Islam sebagai agen konsolidasi dari terwujudnya civiel society memiliki tanggung jawab besar dan mampu memainkan peranan yang lebih besar dalam mendorong sistem demokratisasi yang berlandaskan nilai pluralitas kebangsaan yang diimplementasikan dalam bentuk 
kontributif melahirkan kepemimpinan nasional.

Arief, M. Sarief. 2010. Politik Film di Hindia Belanda. Depok: Komunitas Bambu. . 2010. Politik Film. Depok. Komunitas Bambu.

Barthes, Roland, 2007. Petualangan Semiologi, Yogyakarta: Pustaka Pelajar.

$\begin{array}{lr}\text { Mitos-Mitos } & \text { Membedah } \\ \text { Massa, } & \text { Yudaya } \\ \text { Jalasutera. } & \end{array}$

Danesi, Marcel, 2010. Semiotika Media: Pengantar Memahami Semiotika, Yogyakarta: Jalasutera.

Hamad, Ibnu. 2004. Konstruksi Realitas Politik Dalam Media Massa, Sebuah Studi Critical Discourse Analysis Terhadap Berita-Berita Politik. Jakarta: Granit.

- 2010. Komunikasi Sebagai Wacana. Jakarta: La Tofi Enterprise. 2005. Konstruksi Realitas Politik Dalam Media Massa: Studi Critical Disourse Analysis Terhadap Berita-berita Politik. UI
Hardiman. F. Budi. 2016. Demokrasi Deliberatif, Menimbang Negara Hukum dan Ruang Publik dalam Teori Diskursus Jurgen Habermas. Yogyakarta: Kanisius.

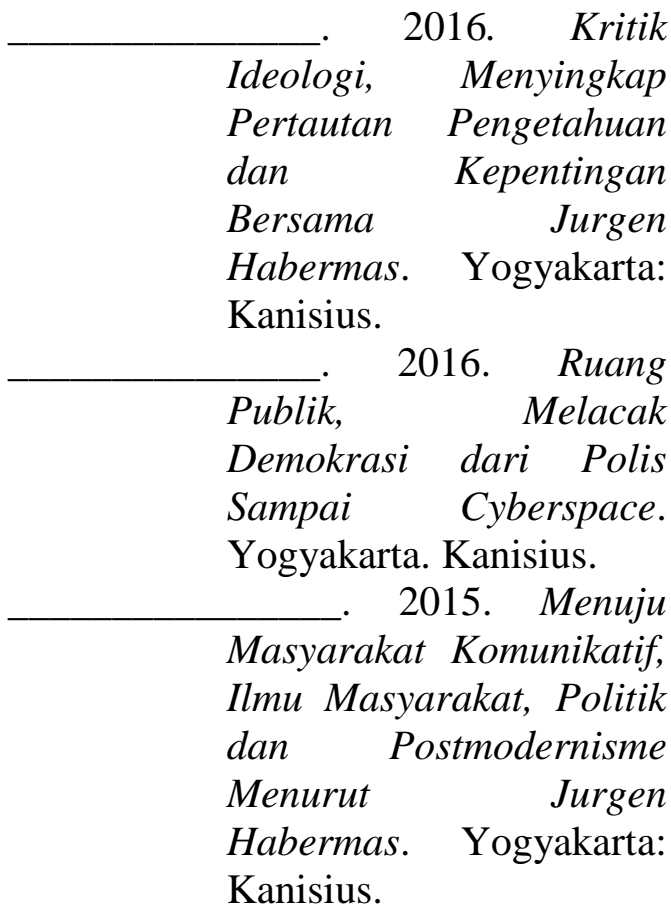

Haryatmoko. 2017. Analisis Wacana Kritis, Landasan Teori, Metode dan Penerapan. Jakarta: Rajawali Pers.

Maarif, Ahmad Syafii. 2015. Islam dalam Bingkai Keindonesiaan dan Kemanusiaan. Bandung: Penerbit Mizan.

Pratista, Himawan. 2008: Memahami Film. Yogyakarta: Homerian Pustaka. 